\section{The Myth of the "Natural CEO"}

Neil Seeman

I hear a lot from "leadership experts" nowadays. There are popular management books about "authentic leaders" - about guys (examples selected tend to be mostly men) who personify that charismatic "it": that unarticulated mix of character traits that constitutes the "natural leader."

I'll bet lots of people called disgraced financial engineer Bernie Madoff a "natural CEO" for most of his life. Now, like a string of once-" natural" CEOs, he's in jail, but there will be many who will forever admire Madoff's robber-baron qualities of "charisma" and "resourcefulness." In a recent book about Cornelius Vanderbilt (aka "Commodore") author T.J. Stiles describes how America's steamship king (and the wealthiest person in the United States in the late 19th century) was widely considered "an economic visionary": a natural. (He was also portrayed by many others as brutally selfish, ruthless and wicked).

The myth of the "natural CEO" is so ingrained in our culture that we scarcely notice it. It is pernicious. The fickle financial media fawn over "natural" CEOs. Ex-Worldcom CEO Bernie Ebbers was hailed by journalists as a "visionary" and "natural" during the company's meteoric rise in the 1990s; now, like Enron's former "natural," Kenneth Lay, Ebbers is a symbol for corporate greed.

The myth of the "natural" is (a) empirically false; and (b) it suggests to people who are not "naturals" that they'll never become CEOs. For centuries, candidates for leadership were only "naturals" if they were white and male, and in with the right crowd. I often wonder how many thousands, millions, of inventions might have emerged from under the sands of time were it not for some person (even if well-intended) who told someone else, "Hey kid, you just don't have 'it'."

I've always thought that the one thing that binds entrepreneurs - entrepreneurs being people who take enormous personal and financial risk to start something crazy and new - is that someone around them told them at one point in their life that they were not a "natural." But instead of swallowing this poisoned rhetorical pill, they set out to prove the naysayer wrong. You're only anointed with "natural" status once you win big. Those who have suffered "the slings and arrows of outrageous fortune" remember the wounds forever.

\section{Are There Any Natural Healthcare CEOs?}

Most people understand instinctively that society as a whole needs to take risks in order to innovate. But there seems to be something about human nature that thinks only a special few, the elusive "naturals," can do this right. It is in our DNA. We worship "natural beauty" and the "born leaders."

This cognitive human conceit about the "natural" can be dangerous in healthcare. Young people don't have - and will likely never again have - linear career paths. It is tempting to recruit to the healthcare CEO's office someone who climbed up a comfortable, linear career ladder (and who exclusively dedicated his or her life to the health sector), because we think these people are "naturals" when, possibly, they were just industrious and lucky. Yes, lucky.

Many, not all, who have reached the height of corporate success know that random events are responsible for much of their fortune. Probability theory teaches that, in any large group of money managers, there has to be a lucky one who consistently beats the market over a long stretch. He or she is no "natural." At the "tails" of life, as Nassim Nicholas Taleb and other randomness scholars explain, we affect our fortunes by strength of character and stamina.

The danger in healthcare is for the CEO to attribute his or her success to "natural" talent. I do not wish for anyone to be a patient in a hospital where the CEO thinks of herself as a "natural." If that's the case, then that CEO - as prone to human failure as any of us - may think of herself as infallible. We all know someone tainted by such arrogance. In healthcare, this hubris can mean an unwillingness to learn from others, a resistance to change, and a preference for going it alone.

I once challenged a "leadership expert's" idea of "natural leadership" on the professional networking site Linkedin [link to the discussion thread requires registration]. This was in response to a question posed by former Medtronic CEO and Harvard Business School Professor Bill George, author of Authentic Leadership He asked: "Which CEO and/or company represents authentic leadership to you and why?" In the 1,128 mini-essay responses to Mr. George, here were the most familiar answers: Warren Buffet (Berkshire Hathaway), Bill Gates (Microsoft), Lou Gerstner (IBM), Jeff Bezos (Amazon), Michael Dell (Dell) and Steve Jobs (Apple). Amazingly, no hospital or healthcare names made the public's list. This in itself suggests that what the public at large considers great leadership is highly skewed: in favour of male, private sector CEOs, and biased toward the technology and finance sectors.

I answered Mr. George's question with the following: "In my view, a great leader is one who admits the humility of knowing that his greatness is largely a function of randomness." I received over 30 emails of support from executives around the world.

None of this is to recommend idleness, waiting for luck to miraculously come our way. It means trying - every day - to take advantage of opportunity before it passes us by, but staying resolutely humble in the face of all good fortune.

Take a chance on chance. But please: Don't tell anyone you know that they're not a "natural leader" or "natural businessperson" or a "natural CEO." You may have just squelched a great idea that could change the world.

\section{About the Author}

Neil Seeman is a writer, and Director and Primary Investigator of the Health Strategy Innovation Cell at Massey College at the University of Toronto. 
